\title{
GREEN MARKETING: A TOOL FOR COMPETITIVE ADVANTAGE
}

\author{
*Prof. Sonu V Gupta ${ }^{* *}$ Prof. Prakash Chawla \& ${ }^{* * *}$ Prof. Sandhya Harkawat
}

\begin{abstract}
There is a growing concern for environmental conservation all over the globe. Environmental issues influence all human activities. Few academic disciplines have already integrated green issues into their literature. The new challenges we face are environmental degradation. Environmental degradation, which was not much a concern until recently, has started to accelerate. Particularly the urban areas have to tackle this issue in a holistic manner in order to ensure sustainable solution, both economically and environmentally. The concept has a crucial importance for the sustainable development of an organization, the country and the whole globe.

In this connection, green marketing is the marketing of products that are presumed to be environmentally safe. It incorporates a broad range of activities, including product modification, changes to the production process, packaging changes, as well as modifying advertising. Companies all over the world are striving to reduce the impact of products and services on the climate and other environmental parameters. Marketers are taking the cue and are going green. In this research paper authors have endeavor to acknowledge certain areas of green marketing and environment protection and the problems to be faced with. The objective of the study is to identify the essentials that motivates for businesses to opt for green marketing. Is also makes an attempt to find out whether green marketing perspective can lead a Company to above average performance vis-à-vis competitors? Questionnaire method used as primary sources and séécondary sources are used to reveal important

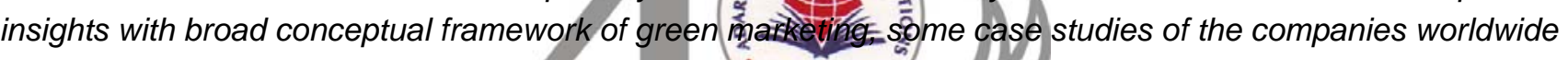
as well as of India with green perspective. The approăch of this study is descriptive type, Percentile method and hypothesis testing with Chi-Square Test has been used for the data analysis purpose. Survey conducted is of 80 respondents to find the awareness regarding the green products in general and for the battery operated vehicles in particular.
\end{abstract}

\section{Introduction}

Marketing is all around us. Whenever we buy a product or service, some type of marketing is involved in that. Customers do have many needs and wants and the basic task of any marketer is to satisfy or solve customer problems at profit. But a whole set of forces that appeared in the last decade like wide spread use internet, faster communication modes, globalization of the world economies etc call for new marketing and business practices.
Companies have developed new capabilities that can transform the way they have been doing marketing and that is what holistic marketing is all about. The holistic marketing concept is based on the development, design and implementation of marketing programs, processes and activities that recognizes their breadth and interdependencies. Holistic marketing recognizes that everything matters with marketing and that a broad, integrated perspective is often necessary. There are four components of holistic marketing :-

\footnotetext{
* Prof. Sonu V Gupta, Director I/c,

S. K. Patel Institute of Management and Computer Studies- MBA, Sector 23, Gh—6 Road, Gandhinagar- 382023, Gujarat, sonugupta2001@gmail.com
}

** Prof. Prakash Chawla, Head of Department-MBA,

S. K. Patel Institute of Management and Computer Studies- MBA, prakashchawla00@ gmail.com

*** Prof. Sandhya Harkawat, Faculty,

S. K. Patel Institute of Management and Computer Studies- MBA 
Relationship marketing,

Integrated marketing,

Internal marketing, and

Social responsibility marketing.

The chart of holistic marketing is given on the next page. Holistic marketing incorporates social responsibility marketing and understanding broader concerns and the ethical, environmental, legal and social context of marketing activities and programs. The cause and effects of marketing clearly extend beyond the company and consumer to society as a whole. One of the important constituent in the society is the natural environment which is being exploited because of many products and services and thus the need for discussion about the green marketing.

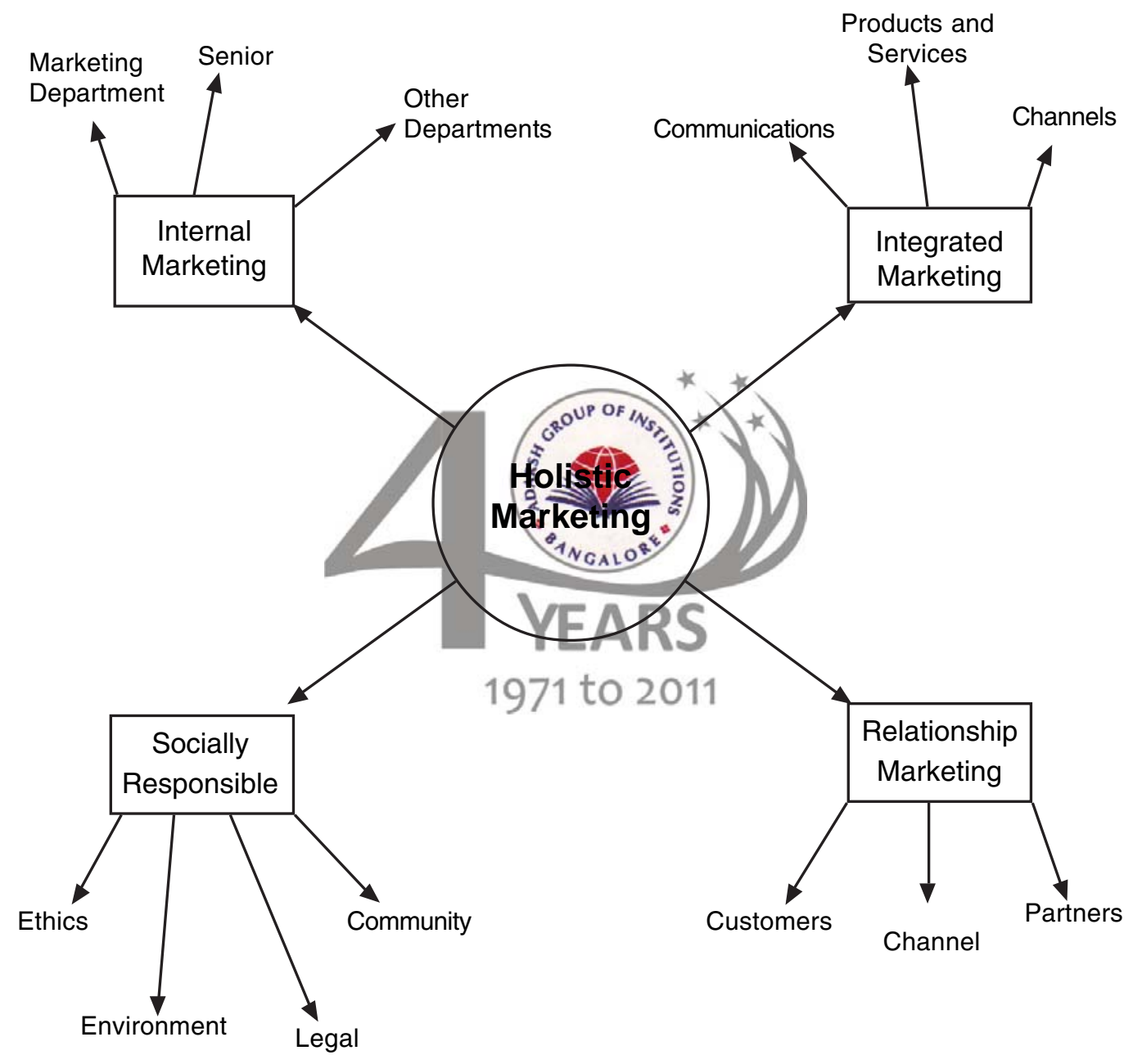

Figure 1 - Holistic Marketing Dimensions

Source: Kotler Philip, Keller Kevin, Koshy Abraham, Jha Mithileshwar

"Defining Marketing for $21^{\text {st }}$ Century" $12^{\text {th }}$ Edition, Pearson Education 


\section{Green Marketing}

Green marketing incorporates a broad range of activities, including product modification, changes to the production process, packaging changes, as well as modifying advertising. Yet defining green marketing is not a simple task. Indeed the terminology used in this area has varied, it includes: Green Marketing, Environmental Marketing and Ecological Marketing.

Green marketing came into prominence in the late 1980s and early 1990s; it was first discussed much earlier. The American Marketing Association (AMA) held the first workshop on "Ecological Marketing" in 1975. the first definition in green marketing is "The implementation of marketing programs directed at the environmentally conscious market segment (Henion 1976).

\section{Green Marketing : A Paradigm Shift}

A new paradigm shift is taking place in marketing. Basic assumptions about how best to cater to consumer needs are in question. Successful green marketers no longer view consumers as individuals with insatiable appetites for material goods, but as human beings concerned about the condition of the world around them, how they themselves interact with the rest of nature, and cognizant of how material goods impact their lives positively as well as negatively, short term as well as long term.

The corporations that excel at green marketing are proactive in nature. Aiming to surpass minimal compliance standards, they define the rules by which they and their competitors will be judged. Ecologically responsive corporations consider themselves to be like nature's processes, interdependent. They ally with corporate environmental stakeholders in cooperative, positive alliances, and work hand in hand with suppliers and retailers to manage environmental issues throughout the value chain. Internally, cross-functional teams convene to find the best possible holistic solution to environmental challenges. Long-term, rather than short-term in their orientation, these companies

omanage with a double bottom line-one bottom line for for ofits, the other one reflecting their contribution to sốciety(Jacquelyn A. Ottman,1998)

\section{(itronos.}

The following table clarifies how the green marketing is different from conventional marketing. ( Dr. Anand Sharma, Dr. Sunil Gupta and Dr. Sushil Sharma, June 2006)

\begin{tabular}{|c|c|c|}
\hline & Conventional Marketing & Green Marketing \\
\hline Consumers & Consumers with life styles & Human being with Lives \\
\hline Products & $\begin{array}{l}\text { Cradle to Grave - One age fits all } \\
\text { products }\end{array}$ & $\begin{array}{l}\text { Cradle to Cradle- Flexible } \\
\text { services }\end{array}$ \\
\hline $\begin{array}{l}\text { Marketing and } \\
\text { Communications }\end{array}$ & $\begin{array}{l}\text { Selling Oriented } \\
\text { End Benefits }\end{array}$ & $\begin{array}{l}\text { Educational } \\
\text { Value driven }\end{array}$ \\
\hline Corporate & $\begin{array}{ll}\checkmark & \text { Reactive } \\
\checkmark & \text { Independent } \\
\checkmark & \text { Competitive } \\
\checkmark & \text { Departmentalized } \\
\checkmark & \text { Short-term oriented } \\
\checkmark & \text { Profit Maximizing }\end{array}$ & $\begin{array}{ll}\checkmark & \text { Pro-active } \\
\checkmark & \text { Interdependent } \\
\checkmark & \text { Cooperative } \\
\checkmark & \text { Holistic } \\
\checkmark & \text { Long term oriented } \\
\checkmark & \text { Double Bottom line }\end{array}$ \\
\hline
\end{tabular}

First consumer survey was conducted by Vandermerwe and Ollif stating that more then $92 \%$ European multinationals clamed to have changed their products in response to green concern. 
Green products introduction increased by more then double to $11.4 \%$ of all new household products in the USA between 1989 and 1990 and continued to rise to $13.4 \%$ in 1991 However this optimistic start to the 1990s was not sustained (Peattie and Crane 2005). A 2001 survey conducted by Roper indicates that during the 1990's approximately $2 / 3$ of all consumers believed that environmental protection and economic development can go hand in hand. While perception is important, actual behavior is crucial to market success. report (conducted by Mintel 1995) showed only a very slight increase in green consumer since 1990 and a significant gap between concern and actual purchasing.

\section{Literature Review}

If we look back to the theories of business and social responsibility, there are basically two views. According to the first, it is the responsibility of business to do something for the development of society in which it operates. Whereas the second view states that the only responsibility of business is to business at a profit. So while addressing the concept of green marketing it is essential to see that what are the motivations for businesses to opt for green marketing? Looking through the literature there are several suggested reasons for firms increased use of Green Marketing. Five possible reasons cited are (i) Organisations perceive environmental marketing to be an opportunity that can achieve its objectives. (Keller 1987, Shearer 1990), (ii) Organisations believe that they have a moral obligation to be more socially responsible, (iii) Governmental bodies are forcing firms to become more responsible.(NAAG 1990), (iv) Competitors' environmental activities pressure firms to change their environmental marketing activities (NAAG 1990); and (v) Cost factors associated with waste disposal or reductions in material usage force firms to modify their behavior (Azzone and Manzini 1994).

Green or Environmental Marketing consists of all activities designed to generate and facilitate any exchanges, intended to satisfy human needs or wants, such that the satisfaction of these needs and wants occurs, with minimum detrimental impact on the natural environment. ( Polonsky 1994b). The paper focuses on product and pricing issues. It examines issues such as what needs to be greened, why consumers purchase / do not purchase green products and how firms should think about information disclosure strategies on environmental claims? (Aseem Prakash, 2002)

The next section is based on the selected worldwide and Indian cases to find out the essentials that what are the motivations for businesses to opt for green marketing?

\section{Green Marketing : Worldwide Practices}

The concept of green marketing evolved in early 1970 s and 1980s. From then many companies worldwide have considered the environmental aspects of their products. Companies started looking at how they can reduce the harm that their products were making to the natural environment. Not only this, but some companies came up with the products and services which had the basic theme UP OFffeenvironment friendliness. Following are some real Aworke company examples that have made changes 数 aspect.

John Deere

The John Deere Company, of Horicon, Wisconsin, enjoys the opportunity it created to save money by pioneering the notion of reusable shipping crates. It chooses to go beyond compliance of state laws prohibiting the land filling or burning of corrugated containers and opts for reusable/returnable plastic containers for the 5,000 plus components arriving at its farm-equipment factories.

\section{Xerox}

Xerox Corporation is a big believer in remanufacturing. No wonder. They have saved $\$ 200$ million in materials and parts cost in less than five years by remanufacturing some of their copiers, using the same assembly line to produce newlymanufactured as well as remanufactured machines.

According the December 2006 report of New York Times, Xerox, in partnership with Palo Alto Research Center (PARC), is working on an "erasable paper" 
for use in copy machines that holds print for 16 hours, and then can go right back into the machine for reuse. The project is, in part, a response to findings showing that almost half of the documents an average worker prints are for single use - most of them end up in the recycling bin the same day (if not in the trash). The project is still in the very early stages.

\section{Wal-Mart}

Since 1989 when Sam Walton launched retailing's first major environmental marketing program, WalMart has been engaged in myriad environmentrelated activities. One of the most notable is the building of an entire green store in Lawrence, Kansas, designed to be environmentally sound from the ground up. The store incorporates features such as sustainably harvested wood, a rooftop rainwatercollection system, solar powered outdoor signage, and a specially designed system of natural "day lighting" that has been linked to increased sales, presumably because of the pleasant environment and the enhanced attractiveness of the merchandise itself.

\section{Canon}

At Canon, a corporate philosophy of "kyosei"-living and working together for the common good-guides the company toward cause-related marketing that reinforces the company's position as a market and environmental leader.

It began with the Clean Earth Campaign in 1990 which donated $\$ 1$ to be divided between the National Wildlife Federation and The Nature Conservancy for each Canon toner cartridge returned to the company. The five-year effort resulted in the recycling of several million toner cartridges along with a corresponding donation. The success of the program inspired Canon to deepen and enhance their cause-related marketing efforts.

\section{Home Depot :}

In the retail home center industry, Home Depot's financial success is not its only distinguishing factor.

The company's strong commitment to environmentalism has won it much kudos from consumers, the government, other businesses, and environmentalists. Home Depot set out to address the challenges of green while meeting the needs of its customers through a variety of programs. The 479-store chain began to seriously incorporate environmentalism into the company in 1990, shortly after the 20th anniversary of Earth Day. Efforts have helped to keep Home Depot among the nation's most admired corporations and among other accolades, in 1996, earned the company an award from the President's Council on Sustainable Development.

\section{Philips}

Approximately 25 percent of electricity generated in the U.S. is used for lighting, costing Americans \$32 billion annually, and representing the power of more than 100 large 1,000 megawatt plants. Thus, every 1 percent improvement in lighting efficiency can offset the need for a new power plant.

One easy way to save energy is to simply turn off the lights. Another is to switch to energy efficient bulbs. Rhilips Lighting now markets a line of compact flư orescent bulbs called the Earth Light Collection. Versatile and attractive, these bulbs save energy and prevent carbon dioxide and sulfur dioxide from being gaureleased into the atmosphere.

\section{E Toyota}

Toyota's Prius may be the first major consumer product that fits nearly all of the criteria for success in the green-consumer marketplace: It comes from a trusted company and can be bought wherever the company's products are sold; it looks and feels like a conventional product and doesn't require consumers to change their habits to use; it is (almost) comparably priced to purchase and can save consumers money to operate; and it has added benefits - it both saves money and it's stylishly cool.

But when the Prius was launched in the U.S. market in 2000, Toyota didn't play up its environmental attributes, according to Ed La Roque, National Advanced Technology Vehicle Manager. The emphasis was on saving gas and money. Those early marketing efforts were aimed at early adapters - the technology buffs that wanted the latest, coolest thing - today's iPod crowd. Environmentalists were a relatively s mall subset of 
that population. The product's original tagline was Prius/genius, showing "not only the intelligence of the new technology but also the creative Web-based marketing approach. The first 2,000 or so vehicles were sold online - a key medium for early adopters.

\section{Whirlpool}

Whirlpool is the world's leading manufacturer and marketer of major home appliances. Headquartered in Benton Harbor, the company manufactures in 13 countries and markets products under 11 major brand names in more than 170 countries.

Whirlpool Corporation's commitment to environmental preservation was recognized by the U. S. Environmental Protection Agency, as it honored Whirlpool with the 1998 Climate Protection Award and the Stratospheric Ozone Protection Award.

With manufacturing facilities in 13 countries, Whirlpool's product design and manufacturing teams have worked in tandem with governments and the scientific community to develop resource-friendly products, recyclable packaging and conservation programs. Traditionally, the company has made great strides in exceeding environmental standards through innovations, advanced technology and an investment in continuous environmental improvements.

\section{Green Marketing : An Indian Perspective}

The term "Green Marketing" is relatively new in the Indian context. The most visible manifestations of corporate activities have been in industries associated with polluting the environment or niche segments in some sectors such as hotels and stationery. Following are some Indian companies, who have adapted their shelves with the green marketing paradigm and gained some type of competitive advantage in the market place.

\section{ITC LIMITED: Paperboards \& Specialty Papers Division}

The pulp and paper industry is one of the most environmentally unfriendly industries in the world. Not only is the industry directly responsible for deforestation, but it is also an energy hog and a large user of chlorine, which is used to bleach the pulp and when released as effluent, ends up polluting water bodies. ITC's Bhadrachalam paper unit, however, has achieved a unique distinction: It was the first paper mill to go chlorine-free. Its investment in the green technology: Rs 500 crore. End of September-2004, the Delhi-based NGO, Centre for Science and Environment, rated the Bhadrachalam unit as the best paper unit in the country. In the Indian market ITC-PSPD commands a market share of $18 \%$ by volume. Since inception ITC PSPD has won 67 awards in various areas out of these, 36 are in Energy and Environment front. In line with its commitment to the society, ITC Foods - a strategic business unit of ITC Limited is, for the third successive year, conducting a nationwide Sunfeast Hara Banao Campaign. The campaign aims at educating children about the growing environmental adversities and how each of them can contribute in "saying the environment".

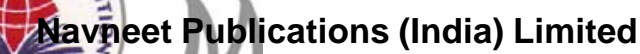

AaAV NEET was floated by the NAVNEET Group of Companies managed by Gala Family Members who have an enviable reputation of over 46 years in the field of Educational Books Publishing.

In 1993, NAVNEET installed machinery to manufacture paper stationery products at Vasai near Mumbai. The company also installed State-of-theArt 'Note Book on-line' machine in 1995 at Daman. The operations at Daman have since been shifted to more specious factory at Silvassa. As Navneet is into the business of stationery where the basic rawmaterial is paper, it had to something for preserving the environment because paper is generally made from trees. To show its responsibility for the natural environment, Navneet Publications came out with Eco-buddy notebooks.

Navneet has undertaken a unique, novel project that will make significant contribution to protect trees by using eco-friendly paper to manufacture Navneet Notebooks. 


\section{Reliance Industries Ltd.}

RIL is the first and only private sector company from India to feature in the 2004 Fortune Global 500 list of 'World's Largest Corporations' and ranks amongst the world's Top 200 companies in terms of profits. Reliance Industries Limited has emerged as 'India's Greenest Company' amongst the private sector with an overall rank of number two in a BT - ACNielsen ORG-MARG survey of shareholder perception published in Business Today's October issue. Reliance Industries ranked highest in the category of companies that - 'develop technologies that do not harm the environment' and 'invest in making your city a cleaner place to stay in'.

As an environmentally responsible corporate entity, the Jamnagar refinery complex of Reliance, which is the world's largest grassroots refinery and the 3rd largest at any single location, has planted more than 25,000 trees last year to the already existing greenbelt. The refinery received the ISO 14001 Certification for its Environment Management System. In recognition of outstanding achievements in Environment Protection, the refinery division was awarded the Greentech Gold Award for excellence in Environment Management in the Petroleum Sector for the year 2002-03.

Reliance's petrochemicals complex at Hazira, which is the world's largest grassroots multi-feed cracker, during the year, commissioned refrigerant recovery instruments for complete recovery of refrigerants that can effect the ozone layer during the year.

\section{Bharat Petroleum}

Bharat Petroleum pioneered the launch of branded fuels in the country in July 2002 with the launch of Speed, high performance petrol. Subsequently BPCL launched Speed 93 petrol with 93 Octane for cars with high compression ratio. Both these products are currently market leaders with market share in excess of $50 \%$. On 31.07.04 Bharat Petroleum launched yet another Brand, this time in the diesel category - Hi-Speed Diesel with fuel technology capable of reducing particle content in emissions while offering other benefits.

\section{HPCL}

State-owned public sector undertaking Hindustan Petroleum Corporation Ltd plans to enter the market with fuel-efficient and eco-friendly green labeled LP gas stoves through its gas outlets across the country. HPCL has signed a memorandum of understanding (MoU) with Malbro Appliances to manufacture these fuel saving gas stoves under the brand name 'Advanta'. The gas stoves are certified by the Bureau of Indian Standards (BIS) to ensure safety confidence among the customers, the company said. "With this stove the customer will be saving 68 per cent of the fuel as compared to ordinary gas stove," Mr. Rajiv Malhotra, Managing Director, Malbro Appliances, said. The products will be available in variants of single burner to five burners in the price band of Rs 600 to Rs 4,000. Malbro has installed capacity of 6,000 pieces per day in their assembly unit in Parwanoo (Himachal Pradesh). ${ }^{46}$ Philips Iñdia

\section{UP OF IN}

Roýal Philips Electronics of the Netherlands is a aloball leader in healthcare, lifestyle and technology, delivering products, services and solutions through valthe brand promise of "sense and simplicity". Philips VEeing the leader in electrical items has been involved in developing various products which would reduce energy consumption and are eco-friendly. For the past six years, Philips has been focusing on a concept which it calls EcoDesign. The idea is simple: Take into account the overall impact of a product. EcoDesign is based on the life-cycle perspective starting right from raw materials production, parts manufacture, product assembly, transport, usage and end-of-life, not only for products developed in-house, but also those purchased.

\section{TATA Group of Companies}

The company's current green policy focuses on five areas of manufacturing - weight of the product, hazardous substances, recyclability, energy consumption, and Packaging. India's oldest industrial house is stepping up efforts to reduce its carbon footprint across the value chain - from manufacturing processes to distribution networks to ecofriendly consumer products. 
- Tata Steel aims to reduce carbon dioxide emissions at its Jamshedpur plant from the current 1.8 tonne to 1.7 tonne per tonne of liquid steel made by 2012 . The ideal global benchmark though is 1.5 .

- Tata Motors is setting up an eco-friendly showroom using natural building material for its flooring and energy efficient lights. Tata Motors said the project is at a preliminary stage.

- The Taj chain, is in the process of creating eco rooms which will have energy-efficient mini bars, organic bed linen and napkins made from recycled paper. But there won't be any carpets since chemicals are used to clean those. And when it comes to illumination, the rooms will have CFLs or LEDs. About $5 \%$ of the total rooms at a Taj hotel would sport a chic eco-room design.

- One of the most interesting innovations has come in the form of a biogas- based power plant at Taj Green Cove in Kovalam, which uses the waste generated at the hotel to meet its cooking requirements.

- Launched a low-cost water purifier made from natural ingredients.

- Another eco-friendly consumer product that is in the works is Indica .

- EV, an electric car that will run on polymer lithium ion batteries. Tata Motors plans to introduce the Indica EV in select European markets this year.

- Tata Steel said it is currently working on more than 17 CDM projects with Ernst \& Young and these projects are at various stages of approval at United Nations Framework Convention on Climate Change.

- Tata Power has said that of the total power it would generate in the next 10 years, $25 \%$ would be from renewable energy sources.

- Tata Motors is collecting environmental and energy data across its dealer and supply chain to compute their carbon footprint and identity opportunities for cutting down on carbon dioxide emission.

\section{Electrotherm India Ltd.}

Indus Elec-trans, a division of Electrotherm (ET), is formed to manufacture electric vehicles and hybrid electric vehicles. Its vision is to offer an efficient, economical and eco friendly future to the Indian transportation. This new Auto division caters to the common man's need for both individual and mass transportation. Fuelled by Innovation, INDUS will strive to provide the futuristic driving solutions through unconventional, environment friendly, innovative yet reliable technology and enduring products.

\section{Methodology}

In this research paper authors have endeavor to acknowledge certain areas of green marketing and environment protection and the problems to be faced with. The objective of the study is to identify the essentials that motivates for businesses to opt for green marketing. Is also makes an attempt to find out whether green marketing perspective can lead a pof Gompany to above average performance vis-à-vis competitors?

Questionnaire method used as primary sources and secondary sources are used to reveal important NGALRSights with broad conceptual framework of green YE $A_{\text {worldwide as well as of India with }}^{\text {markeen }}$ companies 971 to The approach of this study is descriptive type with percentile method used for data analysis. Hypothesis testing with $Z$ test has also been used for data analysis to verify whether green marketing awareness is present across males \& females and since Age as a variable has more than 2 values; Chi square test is used to check, whether green marketing depends on age. Survey conducted is of 80 respondents to find the awareness regarding the green products in general and for the battery operated vehicles in particular.

\section{Hypothesis Testing}

\section{Hypothesis : 1}

Ho1: There is no difference in green marketing awareness between males and females

$\mathrm{H} 11$ : There is a significant difference in green marketing awareness between males and females 


\section{Hypothesis : 2}

Ho2 : Awareness of eco-friendly products is independent of age.

$\mathrm{H} 12$ : Awareness of eco-friendly products varies according to age.

\section{Hypothesis testing formula (calculation done using Excel)}

Z-test: $\quad$ Zcal $=\mid$ p1-p2 $\mid /[P Q(1 / n 1+1 / n 2)]^{1 / 2}$

Chi-square: $\quad \mathrm{X}^{2} \mathrm{cal}=\mathrm{E}(\mathrm{Oi}-\mathrm{Ei})^{2}$

E

\section{Data Analysis}

Out of 80 respondents, Students are $38 \%$,the professionals $29 \%$, Businessman $19 \%$ and housewives $14 \%$

$69 \%$ were aware about the eco-friendly products. The main reason for such a high awareness is just because of e-bikes (yo-bike), CNG auto and the promotion campaign given by Navneet publication for its eco-budy books.

Of the $69 \%$ of the respondents who are aware of the eco-friendly products, only $33 \%$ of them are actually purchase the products. And majority of them are using the eco-buddy books (Navneet),e-bikes and some organic health care products.

$66 \%$ of the owner respondents were satisfied with the mileage of their e-bikes.

In response to the question as to performance of e-bike as against the advertised or stated claims, the response is mixed as $26 \%$ of respondent stated strongly agree, $30 \%$ stated agree, $14 \%$ stated can't say, $38 \%$ stated disagree, $12 \%$ stated strongly disagree.

\section{Hypothesis testing}

\section{Hypothesis: 1}

Ho1: There is no difference in green marketing awareness between males and females

$\mathrm{H} 11$ : There is a significant difference in green marketing awareness between males and females
(1)

\section{Test Statistics:}

$$
\begin{array}{ll}
\mathrm{p} 1=.6393 & \mathrm{p} 2=.8422 \\
\mathrm{n} 1=.3607 & \mathrm{n} 2=.1578 \\
\mathbf{P}=\frac{\mathbf{n} 1 \mathbf{p} 1+\mathbf{n} \mathbf{2} \mathbf{p} 2}{\mathbf{n} 1+\mathbf{n} \mathbf{2}} &
\end{array}
$$

$$
\text { Zcal }=|p 1-p 2| /[P Q(1 / n 1+1 / n 2)]^{1 / 2}
$$

$Z=\frac{(p 1-p 2)-(P 1-P 2) H o}{\ddot{a} p 1-p 2}$

$$
\begin{aligned}
\mathrm{Z} & =\frac{(.6393-.8422)}{.1218}-0 \\
& =-1.6658
\end{aligned}
$$

(2) Level of significance á $=0.05$

(3) Critical Value of $Z$ at á $=0.05=1.96$

(4) 傗 Conclusion:

AS the calculated value of $Z$ falls in the acceptance cogion, it can be concluded that $\mathrm{Ho}$ is accepted. So it can be inferred that there is no significant difference in the awareness about green marketing between males and females.

\section{1 to 2011}

Ho2 : Awareness of eco-friendly products is independent of age.

H12 : Awareness of eco-friendly products varies according to age.

\section{Hypothesis testing formula (calculation done using Excel)}

Z-test: $\quad$ Zcal $=\mid$ p1-p2 $\mid /[P Q(1 / n 1+1 / n 2)]^{1 / 2}$

Chi-square: $\quad \mathrm{X}^{2}$ cal $=\mathrm{E}_{(}(\mathrm{Oi}-\mathrm{Ei})^{2}$

(1) Set up the hypothesis:

Ho: Awareness of eco-friendly products is independent of age.

$\mathrm{H} 1$ : Awareness of eco-friendly products varies according to age. 
(2) Test Statistics

\begin{tabular}{|l|l|l|l|l|l|}
\hline & $<20$ & $20-30$ & $30-40$ & $>40$ & Total \\
\hline Aware & 6 & 34 & 10 & 5 & 55 \\
\hline Not Aware & 0 & 12 & 6 & 7 & 25 \\
\hline Total & 6 & 46 & 16 & 12 & 80 \\
\hline
\end{tabular}

\section{Calculation of $\mathrm{X}^{2}$}

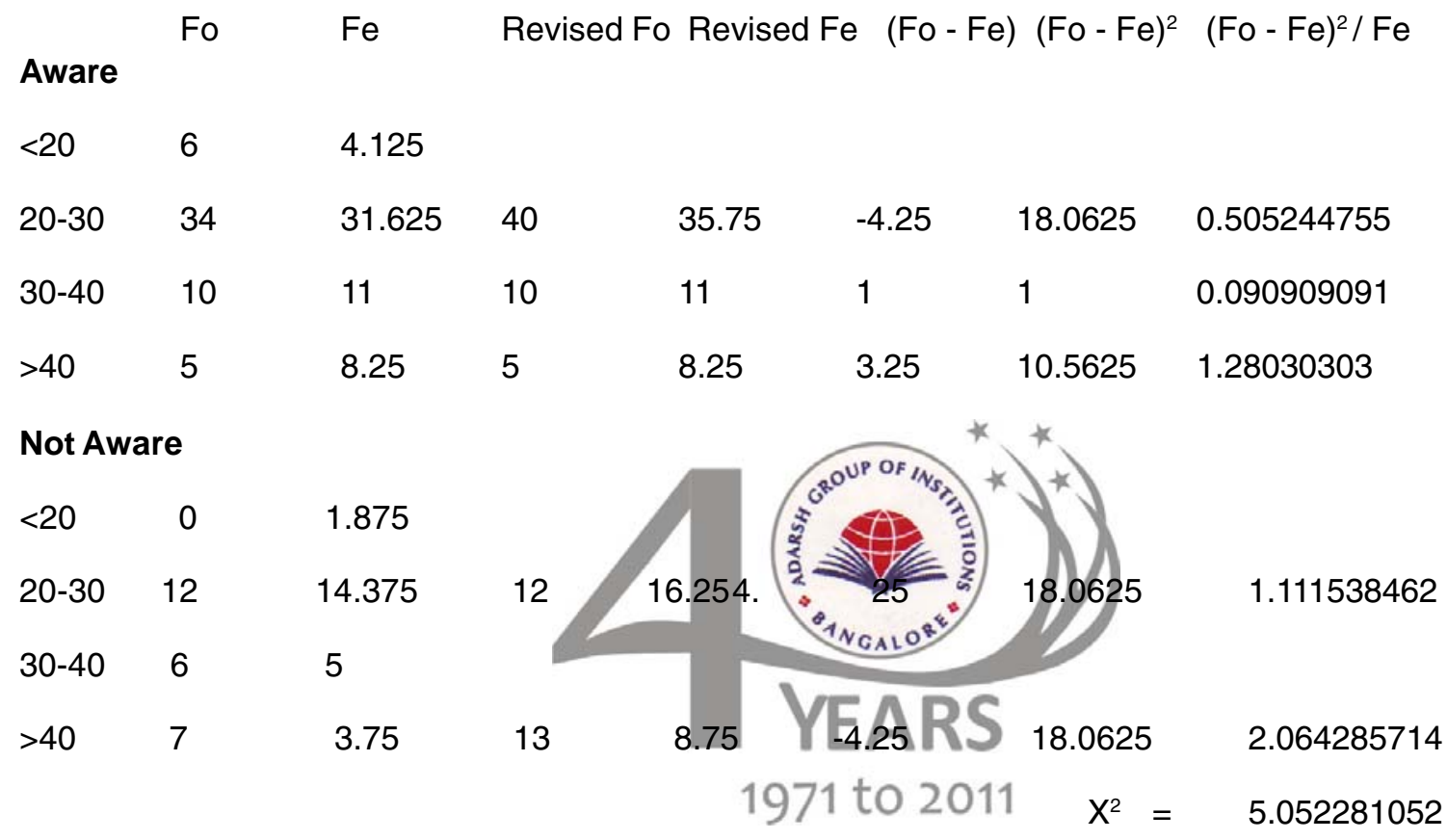

(3) Level of significance á $=0.05$

(4) Degree of Freedom $=(R-1)(C-1)-2$

$$
\begin{aligned}
& =(2-1)(4-1)-2 \\
& =1
\end{aligned}
$$

(5) Critical Value of $\div^{2}$ at d.o.f. $=1, \dot{a}_{0.05}=3.841$

\section{(6) Conclusion}

As the calculated value of $\div^{2}$ falls in the rejection region, it can be concluded that Ho is rejected. So it can be interpreted that there is a clear relationship between the awareness of eco-friendly products and the age of respondents. Thus it can be inferred that green marketing awareness depends on the age. 


\section{Conclusion}

The concept of green marketing evolved in early 1970s and 1980s. From then many companies worldwide have considered the environmental aspects of their products. Companies started looking at how they can reduce the harm that their products were making to the natural environment. A trend that evolved two decades ago in developed markets has just started in India. Over the past few years, some sectors in India have seen green initiatives by firms partly to differentiate their offerings in a competitive milieu and partly to take advantage of the price premium possible. Due to multiple reasons regulatory pressures, technological developments, consumer movement, emergence of niche segments, Indian marketers are going green in new product developments, product modifications and packaging. Through various cases, this is observed that certain companies have practiced the green initiative and gained some type of competitive advantage in the market place. Further form the survey conducted of 80 respondents to know the awareness regarding the green products in general and for the battery operated vehicles in particular, it is observed that the today's generation is aware about these products. Further there is no significant difference in the awareness about green marketing between males and females (Hypothesis 1). There is a clear relationship between the awareness of eco-9 friendly products and the age of respondents (Hypothesis 2)

\section{References}

Michael Jay Polonsky, "An Introduction To Green Marketing", Department of Management, University of Newcastle, Newcastle NSW 2308, Australia.

Ingram, C. Denise and Patrick B. Durst. 1989. "Nature-Oriented Tour Operators: Travel to Developing Countries." Journal of Travel Research 28 (2): 11-18.

Henion, Karl E., and Thomas C. Kinnear. 1976b. "A Guide to Ecological Marketing." in Karl E. Henion and Thomas C. Kinnear (Eds). Ecological Marketing. Columbus, Ohio: American Marketing Association
Dr. Fuller, "Sustainable Marketing: An Overview, University of Central Florida, College of Business, Marketing Department.

Dr. R. Azhagaiah, and A. Hangovan, "Green Marketing and Environmental Protection”, Indian Journal of Marketing, January 2006, p-19-21.

Dr. R. Azhagaiah, and A. Hangovan, “Green Marketing and Environmental Protection Need for Green Marketing", Indian Journal of Marketing, January 2006, p-20.

Jacquelyn A. Ottman, "Green Marketing: Opportunity For Innovation" NTC-McGrawHill, 1998.

K. Suresh, "Green Marketing - The Indian Scenario", Advertising Express, Aug 2006, p-64

Dr. Anand Sharma, Dr. Sunil Gupta and Dr. Sushik Sharma, "Introduction to Green marketing", Prabandh - Journal of Management Éducation \& Research, June 2006,

Green Marketing, Public Policy and Managerial Strategies, by Aseem Prakash, Business Strategy and Environment, 11, 285-292, 2002.

2 Nátional Association of Attorneys-General (NAAG). 1990. "The Green Report: Findings and Preliminary Recommendations for Responsible Advertising". [San Francisco?], USA: National Association of Attorneys-General.

Lalit Sharma, “Green Marketing”, Indian Institute of Foreign Trade, School of International Business Management, New Delhi, h t t p : / w w w. indiabschools.com / marketing_007.htm retrieved on 5/1/2009.

“Xerox Developing Erasable Paper", retrieved from http://sustainablog.blogspot.com/ 2006/12/xerox-developing-erasable-paper.html on $26^{\text {th }}$ February, 2009.

“Wal-Mart's Green Store" http:// w w w. green marketing.com / Green_Marketing_Book/\#wal-mart 
Joel Makower, "Green Marketing: Lessons from the Leaders" retrieved from http:// makower.typepad.com/joel_makower/2006/01/ talking_the_wal.html on $30^{\text {th }}$ January, 2007

http://www.navneet.com/companyinfo.htm

http://www.navneet.com/ecobuddy.htm

“Reliance Group - about us” http://

www.ril.com/html/aboutus/reliance_glance.html

"PHILIPS INDIA - It Does Make Things Better"

http://www.india-today.com/btoday/20010506/ green5.html

Green Marketing, Renewable, and Free Riders: Increasing Customer Demand for a Public

Good
11. Are you satisfied with the mileage of E-bikes? Yes $\square$ No $\square$

12. The performance of E-bikes is consistent as dictated in the user manual.

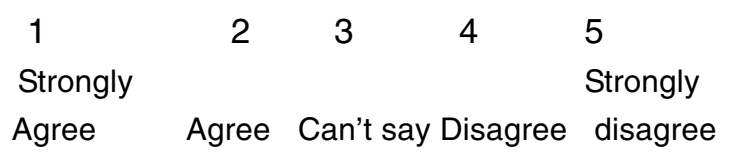

13. Which Value added services would motivate you to buy E-bikes? (Please tick the preferred option)

a. Facility for a spare battery

b. Greater speed

c. Charging points(like at petrol pump)

d. Any Other, please specify

\section{Questionnaire}

1. Name:

2. Gender: $\quad$ Male $\square$

3. Age: $\quad<20 \square \quad 20-30 \square \quad 30-40 \square 40>\square$

4.Occupation: Student $\square \quad$ Businessman $\square$

Professional $\square$ Any other please specify $\square$

5. Are you aware of eco-friendly products?

Yes $\square$ No $\square$

6.Please give the list of eco-friendly products

7. Have you purchased these products?

Yes $\square$ No $\square$

8. Do you have e bike? Yes $\square$ No $\square$

9.Which E-bike do you have?

10. One should use E-bike because....... 